\title{
Transgressing Media Boundaries: News Creation and Dissemination in a Globalized World
}

\author{
Chaker Mhamdi \\ University of Manouba (Tunisia), Al-Buraimi University College (Oman), PO Box 77, PC 512, Buraimi, Oman \\ shaker@buc.edu.om
}

\section{Doi:10.5901/mjss.2016.v7n5p272}

\section{Abstract}

\begin{abstract}
This paper examines how the emergence of social media has transgressed traditional media boundaries and altered models of news creation and dissemination. It investigates the changing patterns of news construction and consumption due to advances on the internet, information technologies, and smart technological devices. Additionally, by examining the role played by social media during the so-called "Arab Spring," the paper studies the effects of social media on the way audiences and journalists receive, gather, and disseminate news, leading to the emergence of "citizen journalism," recently referred to as the "Fifth Estate." At the center of this change is the emergence of social media that brought about a radical metamorphosis in news creation and dissemination. This study examines how the emergence of social media has transgressed traditional media boundaries altering the patterns of news creation and dissemination. The findings indicate that the rising use of social networks allowed individuals to breach geographical barriers and established norms to create hyper-communities where everyone has the opportunity to express themselves freely and to be the center of news. Moreover, this study reveals that rather than competing with one another, social media and traditional mainstream media play complementary roles to provide audiences with instant live news.
\end{abstract}

Keywords: social media, news, Arab Spring, globalization, Fifth Estate

\section{Introduction}

Media today is not the same as the pre-satellite era when audiences had to wait for their morning papers or gathered to watch the evening television news. Similarly, news creation, dissemination, and consumption is no longer the same as the pre-internet period when audiences relied on twenty-four-hour news channels to follow events around the globe. Nowadays, a rising number of readers, viewers, and listeners are going online to seek up-to-date news. Radio, Television, and newspapers, commonly referred to as "traditional media," are still functioning, but not with the same dominance as before in the new and highly competitive environment of interactive online media, which is rapidly transforming the media landscape.

Traditional media has always required the printing process and circulation was limited to a number of geographical locations. Radio and television broadcasting relied heavily on a variety of equipment that is often expensive and difficult to move. In today's globalized world of the information revolution, the rapid pace of new-media technology an increasing number of internet users, and the context of news creation, means media dissemination and consumption has radically changed. Today, anyone can connect to the internet and access a global platform where news is freely available and easily-accessed. Not only has access to news become quicker and easier, but the interactive nature of media and, specifically social media, means that news creation is also possible. An individual with a smart communication device, a camera, or a mobile phone can easily produce instant news and share it with local and global audience. An individual "with a camera or a keyboard is now a non-profit of one and self-publishing is the norm" (Shirky, 2008, p. 77).

Social media, also referred to as "new media," is heavily influencing the established norms of journalism. News media is increasingly a forum for information and debate with anon-linear flow of information and open-sourced journalism. With the interactive aspect of social media, posting a comment, sharing a photo or a video is no longer a mere personal act of entertainment. Interactivity has become a source of news that can be shared and disseminated instantly. Therefore, "the claims that traditional media are the sole champions of authority, objectivity and quality will be (and is being) challenged" (Beckett, 2008, p. 8). Accordingly, this paper investigates the impact of social media on news creation, dissemination, and consumption compared to the era of traditional media monopoly. It examines the role played by social media in reporting news events and their influence on newsrooms operations with a special focus on the lessons learned from the "Arab Spring". 


\section{Literature Review}

According to Dewing (2012), "the term 'social media' refers to the wide range of internet-based and mobile services that allow users to participate in online exchanges, contribute user-created content, or join online communities" (p. 1). Since the 1990s, the web has revolutionized information storage, publishing, searching and consumption. Furthermore, it is argued that "the great wave of web innovation since Google in 1998 has been in social media. Social media is about networking and communicating through text, video, blogs, pictures, and status updates on sites such as Facebook, MySpace, Linkedin or microblogs such as Twitter" (Alejandro, 2010, p. 3).

What gives social media particular importance in journalism is its influential role in communication and breaking news. In many instances, bloggers and social media users have scooped established news channels by instantly disseminating information about major incidents. For example, the death of Michael Jackson in 2009 was a breaking piece of news that appeared first on Facebook and Twitter "ahead of any major news network" (Alejandro, 2010, p. 12). According to Alejandro (2010), "known instances where news is people-driven versus the old way of just being media outlet-driven" are common (p. 12). This has resulted in an inversion in news creation and dissemination from a "top-down" to a "bottom-up" flow.

Many studies show that social media has been attracting increasing numbers of readers and writers (Comscore Media Matrix, 2008; Sifry, 2008). Blogging has gradually matured to become a sort of citizen journalism supporting established journalism and even competing with it (Lenhart \& Fox, 2006). The interactive aspect of blogging lies behind its popularity with users who believe they foster a decentralized flow of information in which citizens have control over news, as opposed to the traditional hierarchical elite monopoly (Rosen, 2006; Weinberger, 2008). It is also argued that social media has enabled the circumvention of high costs that characterized traditional media technologies (Gillmor, 2004; Bowman \& Willis, 2003).

A number of studies have been conducted on the role of traditional media as agenda setters and gate keepers (McCombs, 1997; 2004). In fact, agenda setting is a commonly researched theory in mass communication, first formulated when established media outlets obtained full control over news content and dissemination (McCombs \& Shaw, 1972). Meraz (2009) went one step further in researching agenda setting when she investigated agenda setting to reveal the social influence of elite traditional media outlets among elite newsrooms and political bloggers.

Significantly, a number of studies argue that a huge shift is happening in the media industry and that news is no exception. Due to the global reach of social media networks, "mass media is passé, today it is all about personal media" (Alejandro, 2010, p. 9). Social networking websites have become rapidly growing news sources. According to a Pew Research Center survey in 2012, the number of American adults who regularly receive their news from Facebook and Twitter increased from 7\% to 20\% in a two-year period (Pew Research Center, 2012).

Due to the internet and the widespread use of social media, audiences have access to a variety of news sources where people decide what to read and from which source. Kristof (2009) wrote in a New York Times column "the public is increasingly seeking its news not from mainstream television networks or ink-on-dead trees but from grazing online. When we go online, each of us is our own editor, our own gatekeeper. We select the kind of news and opinions that we care the most about"(p. 6). Hermida et al. (2012) contend that in today's world of new technologies and social networks, sharing is an integral part of news consumption and dissemination. Specifically, they argue that:

Users who are immersed in social media are likely to be more open to receiving news and information via their networked circles, from both peers and journalists. Editorially, the traditional gatekeeping function of the media is weakened as a significant proportion of news consumers turn to family, friends and acquaintances to alert them to items of interest (p. 821)

Accordingly, it is evident from the most recent studies, including Pew Research Center reports, that the role played by mainstream traditional media has been gradually shrinking while news consumption and dissemination through social media has been consistently increasing (Mitchell, 2014). The increased role of digital news from citizen journalists has led to a growing incorporation of user generated content (UGC) into professional news feeds. Media scholars have pointed to the importance of this trend in mainstream media to open pathways that enrich their engagement with audiences and fill gaps in coverage (Deuze, 2008; Napoli, 2011).

\section{Methodology}

Seeking to explore the impact of information technologies and the proliferation of smart devices on the patterns of news production, dissemination, and consumption, this study employs a critical analysis approach that examines the current literature pertaining to the effects of social media on news gathering, creation and broadcasting while simultaneously 
investigating the actual practice of social and traditional media against the major findings of current related literature. More importantly, the methodology utilized in this study extends findings from earlier mass communication research and employs them to a current context, namely that of the so-called "Arab Spring".

Employing a critical analysis approach to today's media practices, as well as the main present literature pertaining to them, in this study implies the application of critical theory in its general meaning following the perspective of Macey (2001) who states that in its broad terms critical theory is "a whole range of theories which take a critical view of society and the human sciences or which seek to explain the emergence of their objects of knowledge" (p. 74). In the same line of thoughts, Payne (1997) defines critical theory as "research projects in the social sciences and / or humanities that attempt to bring truth and political engagement into alignment" (p. 118).

It is worth mentioning that critical theory as a more specific term refers to the previous work of the Frankfurt School which was developed in Germany in the 1930s, and namely of Theodor Adorno, Max Horkheimer, Jurgen Habermas, and Herbert Marcuse where its pioneer start is the work of Karl Marx (Macey, 2001, p. 75). Hence, as Fuchs (2009) concludes, "it is certainly true that critical theory focuses on society, wants to foster political engagement, and wants to show the difference between potentiality and actuality in society" (p. 1).

In this way, this study follows a critical theory approach in its broad definition to divulge the intricate practices of what has been termed "alternative media" and "new media" compared to traditional media giving way to the emergence of "citizen journalism". The methodology adopted in this study aims at uncovering how the proliferation of social media has permitted individuals to transgress media boundaries, geographical barriers and traditional journalistic patterns to create hyper-communities and produce instant news. More precisely, the critical theory investigation in this research rests upon current literature pertaining to the topic under study and tests the investigation in the recent context of the so-called "Arab Spring".

\section{Social Media and News Creation}

In the past, reporters went out to look for news and stories. Nowadays, this is no longer the case as stories are often instantly received through tweets, Facebook posts and blogs. This means stories may already be on social media before they are assigned to a reporter. This changing status quo has compelled reporters to take social media into consideration and find new angles and perspectives on existing information.

Faced with this changing context, journalists find themselves obliged to accelerate the pace of journalistic processes to satisfy the needs of audiences that crave instant information and real-time news. Additionally, a growing number of journalists are now receiving their "scoops" and "breaking" news from web sources. The previous practice of journalists and reporters working on a story until it is fully complete is no longer applicable as this may cause the journalist to be "out-scooped" by a competitor or even an amateur. This risk is made even higher by the global reach of social media networks.

Today, the consumption and reception of news is hugely different from the pre-satellite and pre-internet era. What distinguishes social media from traditional media outlets is its capacity as a communication tool with a global reach and instant news-breaking capability. Many reports reveal that the overall reach of traditional media has been decreasing leaving the way for internet news coverage and social media networks. For instance, the BBC reported that from 2003 to 2008 its reach among audiences aged between 16 and 34 has fallen by more than 7 percent (BBC, 2008).

Another US study revealed that in 2008, 40 percent of the interviewees received their local and global news from internet sources rather than print or twenty-four-hour news channels (Pew Research Centre, 2008). Forecasts expect the growth of bloggers and social networks users, who will have a more control over new creation and dissemination, to continue (Pew Research Centre, 2008). Saffo (2005) states that "In the TV era, it was hard, if not impossible to participate, but now in the world of personal media, the exact reverse is the case (p.6)." Furthermore, as noted, in the US, Facebook has become the number one site, replacing Google (Nuttal \& Gelles, 2010).

These facts are very revealing about the current status of the social media impact on news circulations as well as the future of traditional media. Media outlets no longer have a monopoly over news creation and dissemination. Journalism practices are changing and social networks are leading the race to compete with international twenty-fourhour news channels and established media outlets.

However, this tremendous outreach of social media networks and the instant dissemination of news that characterizes these networks should not conceal their potential drawbacks. There are many instances where the information circulated and shared among Facebook users and bloggers are more than "hearsays" and fake rumors (Singer, 2014). False stories can receive public attention and be disseminated instantly, thereby impacting the people reported. Incases reported, stories were discovered to be false only after damaging the reputation of their victims (Singer, 
2014).

To summarise, social media networks have evidently influenced journalism practices and the news industry. Barriers have been lowered, access to news has become much easier, ordinary people can be the creators of their own news and stories, and they can share them instantly. Nevertheless, the very same social networks may simultaneously pose risks for fraud and fake stories that can mislead and damage reputations.

\section{Social Media Networks as "the Fifth Estate"}

It is commonly known that media are the Fourth Estate in democratic societies where radio, television, and the press play an important and influential role in checking on the separation of legislative, executive, and judicial powers. It is on the basis of this principle that, recently, social media has been termed "the Fifth Estate" by Dutton (2009). Dutton (2009) argues that "we are witnessing the emergence of powerful new voices and networks which can act independently of the traditional media" (p. 3). Ordinary citizens have become creators of news and gate-watchers observing and correcting the mainstream flow of information. Through the use of internet and information technologies, citizens have become producers of instant news in various ways. Furthermore, Newman et al (2012) argue that "The diversity of ways through which the Fifth Estate might improve accountability in politics can be illustrated by several social network sites: Mumsnet, Straight Choice, Vote Match, and MyDavidCameron.com" (p.15). Blogs and related social media have additionally been emerging as sources of "first-hand" news widening the amount and range of news availability. Newman et al (2012) contend that "twitter is used to aggregate comments and source stories, while Facebook and email have become the main forms of distribution and marketing" (p. 16).

Additionally, amateur bloggers, Facebook users, and tweeters do not always challenge mainstream media outlets and compete with them. There are instances where both traditional and social media have worked in cooperation to provide audiences with instant news and real-time coverage. For example, during the London bombing incident of July 2005, the BBC received "more than 1,000 photographs, 20 pieces of amateur video, 4,000 text messages and 20,000 emails" (Sambrook, 2005).

In recognition of the rising importance of social media networks, major media outlets have established centers to gather, examine, and process news and information circulated on social media networks-what has been referred to as "citizen journalism." For instance, CNN has launched the "iReport," a section of CNN.com where audiences can upload their videos and photos instantly. In addition, the BBC established a UGC facility to process information from the public. Consequently, in this new era of the "media age," anyone can report an event, express an opinion, and share a post or a video and, thereby, become a "citizen journalist" to challenge mainstream media's traditional role as the gatekeeper (Newman et al, 2012, p. 14). "UGC" refers to the individuals' creation of content that may be in the form of photos, videos, comments, tweets, and Facebook updates. It has been depicted as news content constructed outside the professional norms and patterns with personal, creative, and individual effort (Singer, 2014, p. 56).Through UGC, individuals can be active producers who report, select and share news and information with wider audiences. In this way, ordinary individuals, or "citizen journalists," have become an integral part of the news flow.

The monopoly of traditional mainstream media over news production and dissemination has been finally called into question by the enhancement of the communicative power of individuals. Social media has enabled individuals to be active producers of news and "citizen journalists" sourcing their own information.

Nevertheless, as noted, the rise of Fifth Estate has also triggered criticism (Keen, 2007). The authenticity, reliability, and credibility of much of the information and news circulated on social media undoubtedly raises questions. Furthermore, exactly as the Fourth Estate can be, in some instances, controlled and channeled by states, elites, and media owners, the Fifth Estate can be influenced by the same factors and anchored by individuals or groups working for hidden agendas.

\section{Social Media in the Arab World: Lessons from the "Arab Spring"}

Social media in the Arab world has been gradually employed to usurp governmental control over the flow of information and restrictions to credible news reports. Seeking to criticize human rights violations, corruption, and the absence of democracy, as well as to increase awareness of information of public interest, Arab bloggers and online activists have resorted to information technologies, social media, UGC and social networks to change the platform of media discourse. In our globalized world witnessing the information technology revolution, online communication between individuals and groups has become easier and more instantly. With the global outreach of social networks, transnational links have been established where ordinary people have become sources of news capable of engaging in political and socio-economic 
activism.

Throughout the so-called "Arab Spring," social media has played a determinant role in shaping media discourse and political debate. In Tunisia and Egypt, social media, also referred to as "new media" and "alternative media," have emerged as new ways for protestors, bloggers, human rights activists, and political dissidents to share their opinions and instantly report government violence and coercive measures against protestors. Social media was also used to resist mainstream media practices and propaganda and, hence, served as means to challenge disinformation. Protestors and activists during the "Arab Spring" stated they "use Facebook to schedule the protests, Twitter to coordinate, and YouTube to tell the world" (Chebib \& Sohail, 2011, p. 139).

The "Arab Spring" was the first time in history that events in the Arab world were reported through social media instead of traditional mainstream media. For the first time, Facebook, Twitter, YouTube, and blogs were the main sources used to follow the progress of events. For instance, during the protests in 2011, 94 percent of the Tunisian people and 88 percent of Egyptians received their news from social media (Sedra, 2013, p.6).

It has become evident that social media had played a paramount role in shaping political discourse and debates throughout the "Arab Spring" period. It is widely argued that the regimes that had fallen progressively in Tunisia, Egypt, Libya, Yemen, and the protestors who took to the streets in Algeria, Morocco, Syria, and other countries in the Arab Gulf, were, in part, facilitated by social media. Howard et al (2011) assert that "The Arab Spring had many causes. One of these sources was social media and its power to put a human face on political oppression. Bouazizi's self immolation was one of several stories told and retold on Facebook, Twitter, and YouTube in ways that inspired dissidents to organize protests, criticize their governments, and spread ideas about democracy" (p. 2).

Social media was heavily employed by protestors and political activists to propagate political discourse and encourage online debate. Whether during or after the uprisings in Tunisia, Egypt, and other Arab countries, "citizen journalists" used Facebook, Twitter, and YouTube to instantly cover instant events and post live videos that revealed government coercion and corruption. Bloggers skillfully disseminated news and information that transgressed government censorship. "In some cases, they used new technologies in creative ways such as in Tunisia where democracy advocates embarrassed President Zine El Abidine Ben Ali by streaming video of his wife using a government jet to make expensive shopping trips to Europe" (Howard et al, 2011, p. 2).

Additionally, it is significant that social media and social networking websites enabled bloggers and activists to connect with wider communities outside their countries. The global outreach of blogs, posts, comments, videos, and tweets helped protestors inform news stories and commentaries in Western countries. This enabled protestors to gain the support of Western leaders who advocated for the Arab peoples' right for democracy, liberty, human rights, and freedom of expression. Howard et al (2011) record that "over 2,200 tweets" were circulated on the day when Ben Ali stepped aside and the number "ballooned from 2,300 a day to 230,000 a day" in the week before Mubarak's resignation (p. 4).

Accordingly, as evidenced by the Arab Spring and globally, the social exchange of news, events, and information through digital media has become a daily routine in the flow of news. Faced by these changing patterns of news creation, dissemination, and consumption, mainstream media organizations and professional journalists find themselves compelled to engage interactively with audiences and collaborate with "citizen journalists". Given that the social exchange of news and information on digital media has become a central driving force of social networks and accelerated the patterns and pace of news creation and consumption, it is evident that social media has heavily influenced news audiences as creators and consumers of news and, thereby, compelling newsrooms to revise their traditional journalism practices.

\section{Conclusion}

In today's globalized world, we live in the "age of media" where the revolution of information technologies has transformed various aspects of our daily lives. At the center of this change is the emergence of social media that brought about a radical metamorphosis in news creation and dissemination. This study examined how the emergence of social media has transgressed traditional media boundaries altering the patterns of news creation and dissemination.

The analysis indicates that the rising use of social networks allowed individuals to breach geographical barriers and established norms to create hyper-communities where everyone has the opportunity to express themselves freely and to be the center of news. Due to social networks, the internet, and smart technological devices, ordinary people can become "citizen journalists" who create their own news, share posts and videos, exchange information, mobilize public opinion, and challenge mainstream media stories.

The significance of social media and its global reach, however remote, has compelled traditional media to use the internet, social networks websites, blogs, and smart technological devices to sustain and develop their communicative power. The study reveals that rather than competing with one another, social media and traditional mainstream media 
play complementary roles in providing audiences with instant live news. However, the analysis also indicates that "citizen journalists" do not always provide accurate or reliable information which, in many instances, can sparkfalse rumors that negatively impact individuals and groups.

In light of this, more systematic research is needed to investigate the nature of audience composition and the precise form of social networks as well as the actual practice of reciprocity between journalists and networked individual and group organizations.

\section{References}

Alejandro, J. (2010). Journalism in the age of social media. Reuters Institute for the Study of Journalism pp. 1-47.

BBC. (2008). Annual report and accounts. Retrieved from http://www.publications.parliament.uk/pa/cm200910/cmselect/cmcumeds/ 515/51504.htm

Beckett, C. (2008). Super media: Saving journalism so it can save the world. Wiley-Blackwell.

Bowman, S. \& Willis, C. (2003). We media: How audience sare shaping the future of news and information. Retrieved fromhypergene. net http://www.hypergene.net/wemedia/download/we media.pdf.

Chebib, N. \&Sohail, R. (2011). The reasons social media contributed to the 2011 Egyptian revolution. International Journal of Business Research and Management. 139-153.

Comscore Media Matrix. (2008). Huffington Post and Politico leadwave of explosive growth at independent political blogs and news sites this election season. Retrieved from http://www.comscore.com/press/release.asp?press=2525.

Deuze, M. (2008). Corporate appropriation of participatory culture. In N. Carpenter \& B. D. Cleen (Eds.) Participation and media production: Critical reflections on content creation (pp. 27-40). Newcastle, UK: Cambridge Scholars.

Dewing, M. (2012). Social media: An introduction. Library of Parliament Publication NO. 2010-03-E. 1-5.

Dutton, W. H. (2009). The fifth estate emerging through the network of networks. Prometheus 27(1), 1-15.

Fuchs, C. (2009). Critical theory of information, communication, media, technology. Glossarium-BITri. Retreved from http/l:glossarium. bitrum.unileon.es/Home/teoris-critica-de-la-informatio/critical-theory-of-information.

Gillmor, D. (2004). We the media: Grassroots journalism by the people, for the people. Sebastopol, CA: O'Reilly.

Hermida, A., Fletcher, F., Korell, D., \& Logan, D. (2012). Share, like, recommend. Journalism Studies 13 (5-6), 819-831.

Howard, P. N., Duffy, A., Freelon, D., Hussain, M., Mari, W., \& Mazaid, M. (2011). Opening closed regimes: What was the role of social media during the Arab spring? Working paper project on information technology \&political Islam. 1-27.

Keen, A. (2007). The cult of the amateur: How today's internet is killing our culture. New York: Doubleday.

Kristof, N. (2009). The daily me. The New York Times. March 19, 2009.

Lenhart, A. \& Fox, S. (2006). Bloggers: A portrait of the internet's new storytellers. Pew Internet and American Life Project. Retrieved from http://www.pewinternet.org/pdfs/PIP\%20Bloggers\%20Report\%20July\%2019\%202006.pdf.

Macey, D. (2001). The penguin dictionary of critical theory. London: Penguin.

McCombs, M. (1997). Building consensus: The news media's agenda setting roles. Political Communication 14(4), 433-443.

McCombs, M. (2004). Setting the agenda: The mass media and public opinion. Cambridge, England: Policy Press.

McCombs, M. \& Shaw, D. (1972). The agenda-setting function of mass media. Public Opinion Quarterly 36(2), 176-187.

Meraz, S. (2009). Is there an elite hold? Traditional media to social media agenda setting influence in blog networks. Journal of Computer-Mediated Communication. 14682-707.

Mitchell, A. (2014). State of the news media 2014: Overview. Pew Research Centre. Retrieved from http://www.journalism.org/2014/ 03/26/state-of-the-news-media-2014-overview/

Napoli, P.M. (2011). Audience evolution: New technologies and the transformation of media audiences. New York: Columbia University Press.

Newman, N., Dutton, W.H., \& Blank, G. (2012). Social media in the changing ecology of news: The fourth and fifth estate in Britain. International Journal of Internet Science 7(1), 6-22.

Nuttal, C., \& Gelles, D. (2010). Facebook becomes a bigger hit than Google. Financial Times.

Payne, M. (1997). A dictionary of cultural and critical theory (Ed.) Malden, MA: Blackwell.

Pew Research Centre. (2008). Report of the Pew Research Center for the people \& the press.

Pew Research Centre. (2012). In the changing news Landscape, even television is vulnerable.

Rosen, J. (2006). The people formerly called the audience. Retrieved from http://jounalism.nyu.edu/pubzone/weblogs/pressthink/ 2006/06/27/ppl_frmr.html.

Saffo, P. (2005). Farewell information, it's a media age. Retrieved from Saffo.com.

Sambrook, R. (2005). Citizen journalism and the BBC. Retrieved from Nieman reports

Sedra, K. (2013). The role of social media \&networking in post-conflict settings. African Development Bank Conference. 1-12.

Shirky, C. (2008). Here comes everybody: The power of organizing without organizations. New York: The Penguin Press.

Sifry, D. (2008). State of the blogosphere. Retrieved from Technorati http://technorati.com/blogging/state-of-the-blogosphere/.

Singer, J. B. (2014). User-generated visibility: Secondary gate keeping in a shared media space.New Media and Society16,55-73.

Weinberger, D. (2008). Everything is miscellaneous. New York: Henry Holt. 